\title{
Collagen membrane wrapping around methotrexate-containing calcium-phosphate cement reduces the side effects on soft tissue healing
}

\author{
Metotreksat içeren kalsiyum fosfat çimentosu etrafına kollajen membran sarımı \\ yumuşak doku iyileşmesindeki yan etkileri azaltır
}

\author{
Anıl S. Uzun, M.D., ${ }^{1}$ Alp Akman, M.D., ${ }^{2}$ A. Fahir Demirkan, M.D., ${ }^{2}$ \\ Semih Akkaya, M.D., ${ }^{2}$ Gamze Gököz Doğu, M.D. ${ }^{3}$ \\ 'Department of Orthopedics and Traumatology, Akşehir State Hospital, Konya, Turkey \\ ${ }^{2}$ Department of Orthopedics and Traumatology, Medical Faculty of Pamukkale University, Denizli, Turkey \\ ${ }^{3}$ Department of Medical Oncology, Medical Faculty of Pamukkale University, Denizli, Turkey
}

\begin{abstract}
Objectives: This study aims to evaluate whether the collagen membrane (membrane) wrapping around the methotrexate (MTX)-containing calcium-phosphate cement $(\mathrm{CPC})$ reduces the side effects on soft tissue healing.

Material and methods: In 36 rats, femoral bone defects were created and treated in six groups which were CPC only, $\mathrm{CPC}$ and membrane wrapping around, CPC containing 2\% MTX, CPC containing 2\% MTX and membrane wrapping around, CPC containing 5\% MTX, CPC containing 5\% MTX and membrane wrapping around.
\end{abstract}

Results: Histological examinations revealed a statistically significantly improved healing in the connective tissue samples of the CPC containing 5\% MTX group wrapped around by membrane compared to those without membrane $(\mathrm{p}=0.04)$. However, this was not seen in other groups.

Conclusion: Membrane wrapping around the CPC containing MTX reduces the side effect of MTX on cellular proliferation at its highest concentration, particularly. Membrane wrapping may allow administration of higher doses of an anti-neoplastic drug which can be more effective.

Keywords: Animal model; calcium-phosphate cement; collagen membrane; methotrexate; soft tissue healing.
Chemotherapy plays an important role in eradicating malignant bone tumors and bone metastasis. Although several anti-neoplastic drugs can be intravenously administered, systemic deliveries of these drugs exert many side effects on other
Amaç: Bu çalışmada metotreksat (MTX) içeren kalsiyumfosfat çimentosu (KFÇ) etrafına kollajen membran (membran) sarımının yumuşak doku iyileşmesindeki yan etkileri azaltıp azaltmadığg değerlendirildi.

Gereç ve yöntemler: Otuz altı sıçan femurunda kemik defekti oluşturuldu ve sadece KFÇ, etrafı membranla sarılmış $\mathrm{KFÇ,} \mathrm{\% 2} \mathrm{MTX} \mathrm{içeren} \mathrm{KFÇ,} \mathrm{etrafı} \mathrm{membranla} \mathrm{sarılmış} \mathrm{ve} \mathrm{\% 2}$ MTX içeren KFÇ, \%5 MTX içeren KFÇ, etrafı membranla sarılmış ve \%5 MTX içeren KFÇ şeklinde altı grupta tedavi uyguland.

Bulgular: Histolojik incelemelerde bağ dokusunda etrafı membranla sarılmış \%5 MTX içeren grupta, membran içermeyen \%5 MTX'li gruba göre istatistiksel anlamlı şekilde daha iyi bağ doku iyileşmesi görüldü ( $\mathrm{p}=0.04)$. Diğer gruplarda buna rastlanmadi.

Sonuç: Metotreksat içeren KFÇ’nin etrafının membran ile sarılmasının, MTX'in hücresel çoğalma üzerinde, özellikle yüksek konsantrasyonlardaki yan etkilerini azaltır. Membran sarımı, antineoplastik ajanların daha yüksek konsantrasyonlarda verilmesini sağlayarak, daha etkili tedavi verilmesini sağlayabilecektir.

Anahtar sözcükler: Hayvan modeli; kalsiyum-fosfat çimento; kollajen membran; metotreksat; yumuşak doku iyileşmesi.

organs. The management includes the removal of macroscopic involvement and internal fixation after curettage of the tumor (if needed), followed by chemotherapy and/or radiation. However, this is not always sufficient for local disease control. Therefore

- Received: December 18, 2013 Accepted: May 28, 2014

- Correspondence: Alp Akman, M.D. Pamukkale Üniversitesi Tıp Fakültesi Ortopedi ve Travmatoloji Anabilim Dalı, 20070 Kınıklı, Denizli, Turkey. Tel: +90 258 - 4440728 Fax: +90 258 - 2134922 e-mail: alpakman@gmail.com 
a high concentration of an anti-cancer drug locally would be desirable. ${ }^{[1]}$

Calcium-phosphate cement (CPC) can be used as a carrier to deliver these agents locally and can be effectively directed to affect neoplastic cells. Calciumphosphate cements have a large potential as drug carriers due to their high specific surface area, ${ }^{[2,3]}$ The effectiveness of CPC containing methotrexate (MTX) has been studied before. ${ }^{[4]}$ Burst release of drug from CPC cause adverse local and systemic side effects, when the anti-neoplastic drug is used in high amounts or concentrations. ${ }^{[5]}$ Hence, we hypothesized that collagen membrane (membrane) wrapping around a chemotherapeutic agent incorporated CPC can prevent local side effects on soft tissue healing.

\section{MATERIAL AND METHODS}

In this study, 36 Wistar rats aged 8-12 weeks weighing 200-250 grams were used. The study was approved by the local ethics committee.

Animals were maintained in controlled conditions (at $22{ }^{\circ} \mathrm{C}$ temperature, 12 hours of daily light and 12 hours dark). Xylazine hydrochloride $(10 \mathrm{mg} / \mathrm{kg})$ and ketamine $\mathrm{HCl}(60-100 \mathrm{mg} / \mathrm{kg})$ in combination were given intraperitoneally. The mean duration of anesthesia was approximately one hour. Prophylactic antibiotherapy was not used during or after the operation. No wound infections were encountered.

Norian SRS (Skeletal Repair System ${ }^{\circledR}$; Synthes, Switzerland) is probably the most widely documented CPC. ${ }^{[6-8]}$ Fifty grams of CPC were mixed with methotrexate 100 and $250 \mathrm{mg}$ (DBL Methotrexate $^{\circledR}$ Injectable Solution $50 \mathrm{mg} / 2 \mathrm{ml}$, Orna Pharmaceutical, Turkey) solutions, respectively. Finally 2\% and 5\% mixtures of MTX CPC were obtained. The Membrane (BoneProtect Membrane ${ }^{\circledR}$, Dentegris $\mathrm{GmbH}$, Duisburg, Germany) used in this study was provided in sterile packs of $30 \times 40 \mathrm{~mm}$ in size. The appropriate sizes were cut under sterile conditions before application.

Thirty-six rats were divided into six groups. In all groups, mid-shaft osteotomies of the femur were performed, fixed with intramedullary Kirschner wires (K-wires), and created gaps were re-filled with CPC. The only differences between groups were the incorporation of MTX with or without the membrane wrapping around. According to this: first group; only CPC (control group), second group; CPC and membrane wrapping around, third group; CPC containing 2\% MTX, fourth group; CPC containing 2\% MTX and membrane wrapping around, fifth group; CPC containing 5\% MTX and sixth group; CPC containing 5\% MTX and membrane wrapping around were created.

After anesthesia was given; a $2 \mathrm{~cm}$ lateral incision was made to the right thigh and the femoral shaft was exposed through the vastus lateralis muscle. After the periosteum was incised, a transverse femoral osteotomy was made with an osteotome, and approximately $5 \mathrm{~mm}$ gap was created. The osteotomy was fixed with a $1.2 \mathrm{~mm} \mathrm{~K}$-wire inserted through the greater trochanter. The tip of the K-wire was bent over the greater trochanter and left under the skin. The membranes were cut in appropriate sizes with sufficient overlapping and soaked with sterile $0.9 \%$ saline solution before wrapping around the osteotomy line. As the collagen became wet, it collapsed and adhered to what it covers. ${ }^{[9]}$ As a result, no fixation method was required for the membrane (Figure 1).

In each group, two rats were sacrificed at three, seven and 14 days after administration of a high-dose anesthetic and the right femurs were disarticulated from the hip and knee joints. The specimens were processed and sectioned and stained with Harris Hematoxylin-Eosine solution (Sigma-Aldrich Co., St. Louis, MO, USA). Inflammatory cells were counted in the muscle and subcutaneous connective tissue sections randomly assigned 20 fields for each rat. The mean counts were recorded (x20 magnification).

According to day of sacrification, three day groups also established for the connective and the muscle tissue seperately.
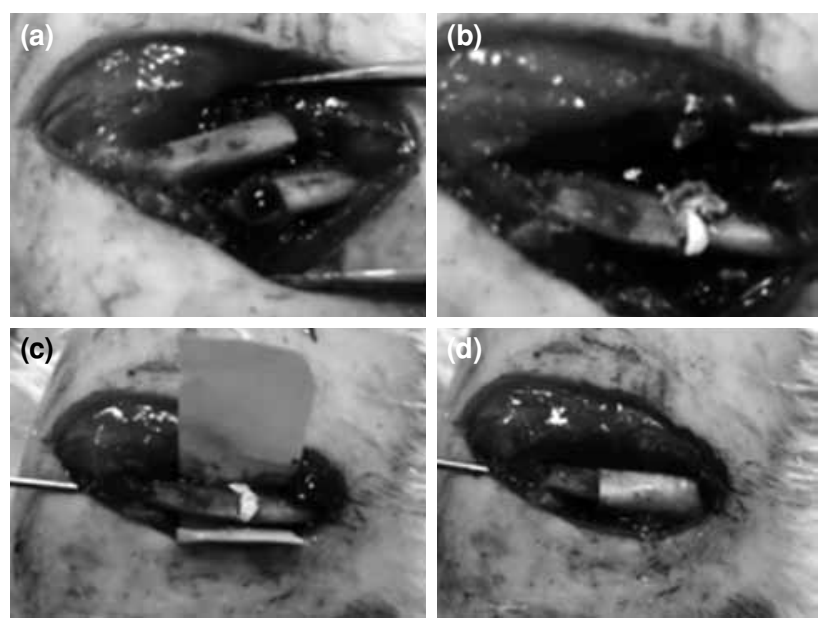

Figure 1. The application of calcium-phosphate cement with or without methotrexate and membrane wrapping around. (a) The transverse femoral osteotomy space was created. (b) The osteotomy line was filled with calcium-phosphate cement with or without methotrexate. (c) Appropriately cut membrane was placed for wrapping and, (d) the procedure was completed. 

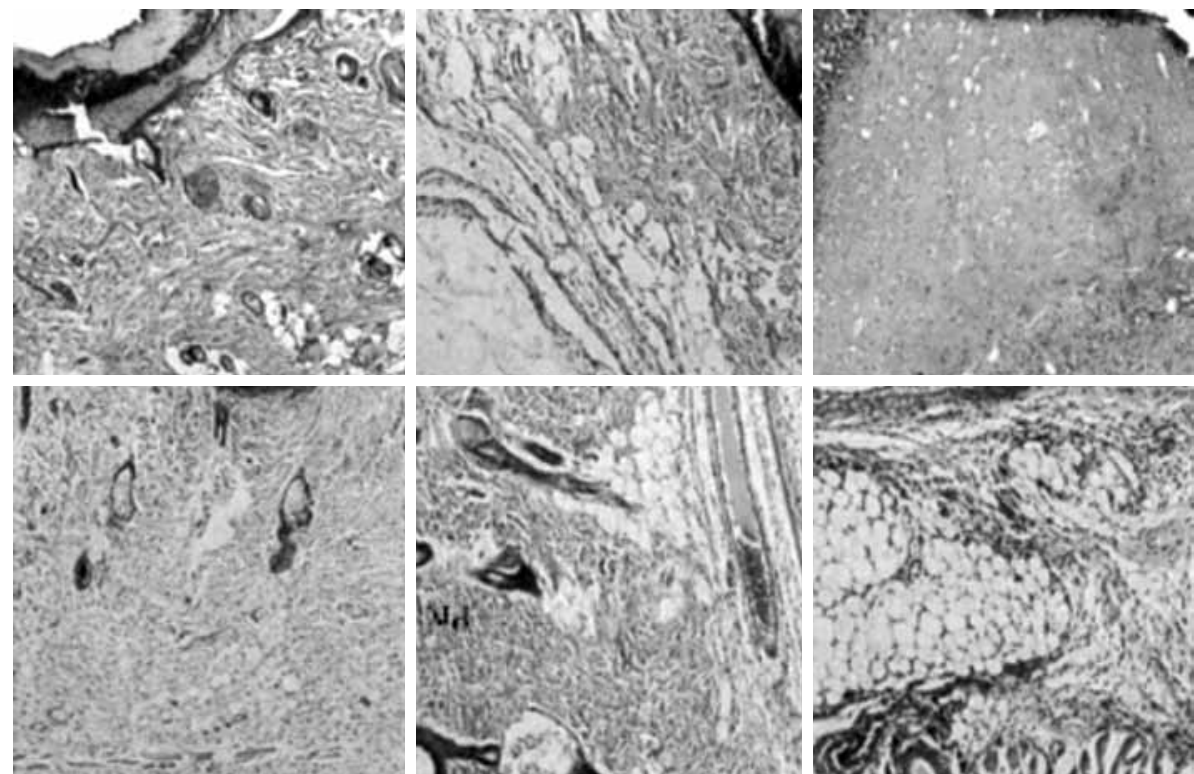

Figure 2. Microscopic examination for groups in the connective tissue $(H-E \times 20)$.

The results were analyzed statistically with non-parametric Wilcoxon signed ranks and NPAR tests. A 95\% confidence level was selected to define significance for all statistical tests.

\section{RESULTS}

There were no significant differences in the cell counts of connective tissue and muscle tissues among the groups. However, the cell density in the connective tissue was greater than that of muscle tissue which was statistically significant in all groups $(p<0.05)$ (Figure 2 and 3 ). In the comparison of the groups with and without membrane, there were statistically significant differences in the connective tissue of the 5\% MTX added groups (group 5 and 6). ( $\mathrm{p}=0.04$ ) (Table 1). It suggests that the membrane wrapping around the MTX added CPC may reduce the expected adverse effect of MTX on cellular proliferation at the highest concentration, particularly.

The animals were sacrificed at three, seven, and 14 days, there were three groups for both connective tissue and muscle tissue each containing 12 animals. The average number of cells in the connective and muscle tissue is shown in Table 2. When the results
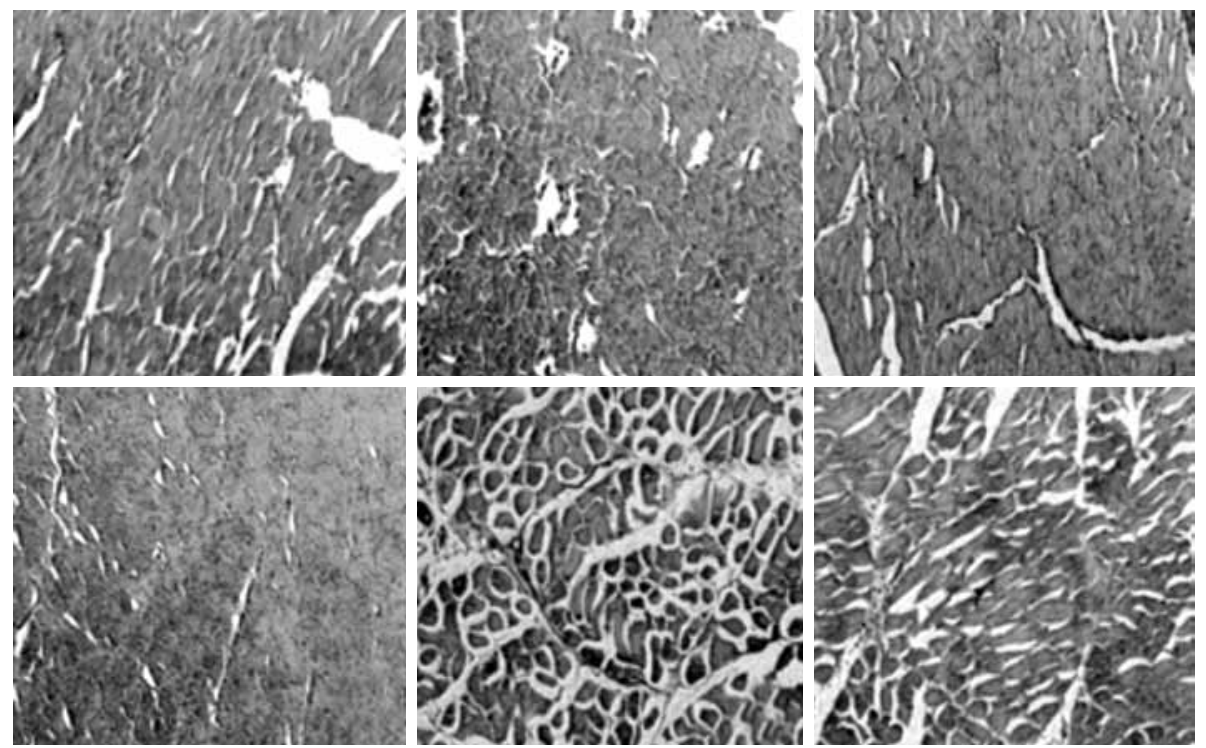

Figure 3. Microscopic examination for groups in the muscle tissue $(H-E \times 20)$. 
TABLE I

Results for the connective and muscle tissue

\begin{tabular}{lccc}
\hline Groups & $\begin{array}{c}\text { Connective } \\
\text { tissue }\end{array}$ & & $\begin{array}{c}\text { Muscle } \\
\text { tissue }\end{array}$ \\
\cline { 2 - 2 } & Mean \pm SD & & Mean $\pm S D$ \\
\hline CPC & $43.42 \pm 7.83$ & & $33.13 \pm 6.88$ \\
CPC + membrane & $41.85 \pm 14.41$ & & $26.43 \pm 5.19$ \\
CPC + 2\% MTX & $40.77 \pm 14.50$ & & $29.75 \pm 8.21$ \\
CPC + 2\% MTX + membrane & $50.47 \pm 7.02$ & & $34.59 \pm 3.86$ \\
CPC + 5\% MTX & $40.40 \pm 11.47$ & & $27.30 \pm 2.86$ \\
CPC + 5\% MTX + membrane & $55.02 \pm 10.70$ & & $31.08 \pm 3.89$ \\
\hline
\end{tabular}

SD: Standard deviation; CPC: Calcium-phosphate cement; MTX: Methotrexate.

were analyzed, the only statistically significant difference was a significant reduction in the cell count at the $14^{\text {th }}$ day compared to the third and the seventh days in the connective and muscle tissue ( $p=0.05$ and $p=0.002$ respectively). The results led us consider that it was a normal physiological process, as the tissue healing subsided at 14 days.

\section{DISCUSSION}

Filling the defects with bone cement supports the bones during fracture healing. ${ }^{[10]}$ The bone filling materials also offers an opportunity to administer the drug treatment locally, thus, improving effectiveness and toleration of high-dose chemotherapy. ${ }^{[1]}$ Chemotherapeutic agents used in adjuvant tumor treatment are known to exert effects on rapidly proliferating cells, and a delaying influence by such agents on wound, and fracture healing may therefore be expected. ${ }^{[12]}$

It has been recently suggested that adding chemotherapeutic drugs to Poly(methyl methacrylate) (PMMA) which may improve the local control of skeletal neoplasms by exerting a direct cytotoxic effect on residual cancer cells. ${ }^{[13]}$ Particularly, incorporation of chemotherapeutic agents such as MTX to bone cement has been reported and the diffusion of the drug from the implanted cement has been demonstrated both in vitro and in vivo. ${ }^{[14]}$ It has been reported that incorporation of different chemotherapeutic drugs (such as methotrexate, doxorubicin and cisplatinum) to PMMA were able to exert a cytotoxic effect in vitro models of human breast cancer cells. It has been also demonstrated that MTX is the drug showing the slowest release with a more prolonged toxic effect over time, thereby, confirming its suitability for this type of application. ${ }^{[15]}$

Several studies reported the addition of methotrexate to bone fillers, usually PMMA bone
TABLE II

Results for the connective and muscle tissue in the day groups

\begin{tabular}{lccc}
\hline Groups & $\begin{array}{c}\text { Connective } \\
\text { tissue }\end{array}$ & & $\begin{array}{c}\text { Muscle } \\
\text { tissue }\end{array}$ \\
& Mean \pm SD & & Mean $\pm S D$ \\
\hline Third day & $45.91 \pm 13.18$ & & $31.70 \pm 5.99$ \\
Seventh day & $50.87 \pm 12.22$ & & $33.23 \pm 4.87$ \\
Fourteenth day & $39.18 \pm 7.25$ & & $25.72 \pm 3.64$
\end{tabular}

SD: Standard deviation.

cement. ${ }^{[16,17]}$ However, PMMA could only create a burst release. Furthermore the temperatures involved in the polymerization exceeded $60{ }^{\circ} \mathrm{C}$, which was harmful for the surrounding tissues potentially, in poor healers such as treated cancer patients, in particular. Calcium-phosphate cements on the other hand are biocompatible and are well used for bone filling applications. ${ }^{[18]}$ Due to their chemical and crystalline affinity to bone tissue, CPC can be resorbed and replaced with bone tissue in vivo. ${ }^{[19]}$ Therefore, we selected a local drug delivery model by using CPC as a carrier for chemotherapeutic agent and MTX as chemotherapeutic agent.

The MTX-CPC local drug delivery system on bone healing has been studied before. It has been found that MTX has not significantly altered the cement setting time and the compressive and tensile strengths of the MTX containing CPC. It has been also shown that MTX release was with a burst effect in the initial stage and a sudden drop thereafter. It has been estimated that the incorporated MTX could be continuously released over two to four months at a higher than minimum concentration. ${ }^{[4]}$

The sustained release of chemotherapeutic drugs at a local site may reduce systemic side effects, however, not free from other side effects. The local administration of anti-cancer drugs may induce severe damage to the surrounding tissue including the skin. In a rabbit model, it was shown that MTX release from the implantation site inhibited osteogenesis in the initial period; this inhibition weakened with time, and no difference was observed between CPC and MTX-CPC at six months of follow-up. The MTX had no apparent toxicity on the host rabbits, even at the highest dose tested. ${ }^{[20]}$ The maximum MTX concentration used was $1 \%$, which is quite less than our results (5\%). Although much more local side effects were expected in our study, we did not encounter such events. 
The experimental and clinical researches on CPC were associated with an increased risk of blood clotting. ${ }^{[21]} \mathrm{A}$ most likely explanation is that clotting is provoked by interfacial reactions between solid particles and blood. Therefore, the release of calcium phosphate particles from the cement into the blood stream should be prevented and/or controlled. ${ }^{[18]}$

This collagen based membrane are mechanically malleable, adaptable, and easy to manipulate, which thought to be beneficial in our experimental application for further controlling drug release from CPC and the release of calcium phosphate particles into the blood. The other advantageous properties of collagen include hemostatic function, facilitating early wound stabilization, semipermeability, allowing nutrient passage, natural enzymatic degradation, and chemotactic ability to attract fibroblasts. ${ }^{[22]}$

Furthermore, the unique character of the collagen matrix provides five major advantages: (i) partial open porosity for quick release of the drug after implantation into the tissue, (ii) partial close porosity for "secondary" release of the drug enclosed within pores, (iii) "tertiary" release of the drug partially immobilized within the fibrillar collagen structure, (iv) a three-dimensional structure which works as a 'natural' distance barrier between the drug incorporated into the sponge and the surrounding environment and $(v)$ a network which enhances cell penetration and new tissue formation. ${ }^{[23]}$ In our experiment, it was hypothesized that the membrane could function as a storage carrier-like CPC- or a diffusion barrier. To the best of our knowledge, this is the first study in the literature investigating the comparative effects of CPC, MTX and membrane on soft tissue healing. As afore mentioned above, the effect of membrane wrapping was prominent in the connective tissue rather than the muscle tissue, particularly. The mean cell density and the protective effect of membrane was less in the muscle tissue. When tissues are disrupted following injury, connective tissue repair is needed to fill the defect and restore anatomic structure and function. ${ }^{[24]}$ Therefore, the protective effect of membrane was centered on the important part of the soft tissue healing.

In conclusion; MTX loaded CPC is a suitable material for the local control of bone tumors and for the filling the cavities after tumoral tissue removal. Collagen membrane wrapping around is an effective method to prevent local adverse effects of MTX release from the CPC with or without CPC's blood clotting triggering action. Furthermore, an enhancement was noticed in the connective tissue at the highest MTX concentration (5\%), particularly. Thus, collagen membrane wrapping may allow administration of higher doses of an anti-neoplastic drug which can be more effective. We believe that further researches are needed to conclude regarding the beneficial effects of collagen membrane wrapping.

\section{Declaration of conflicting interests}

The authors declared no conflicts of interest with respect to the authorship and/or publication of this article.

\section{Funding}

The authors received no financial support for the research and/or authorship of this article.

\section{REFERENCES}

1. Tani T, Okada K, Takahashi S, Suzuki N, Shimada Y, Itoi E. Doxorubicin-loaded calcium phosphate cement in the management of bone and soft tissue tumors. In Vivo 2006;20:55-60.

2. Lee D TA, Kuhn L, Rey C, editor. Calcium phosphate: carrier for therapeutic agents. Florence: Techna Srl.; 2003.

3. Sahin E. Synthesis and Characterization of Calcium Phosphate Cement Based Macroporous Scaffolds [Ph.D.]. İzmir: Institute of Technology; 2012.

4. Yang Z, Han J, Li J, Li X, Li Z, Li S. Incorporation of methotrexate in calcium phosphate cement: behavior and release in vitro and in vivo. Orthopedics 2009;32:27.

5. Rudolph R, Stein RS, Pattillo RA. Skin ulcers due to adriamycin. Cancer 1976;38:1087-94.

6. Clark DW, Ribbans WJ. Treatment of unstable intertrochanteric fractures of the femur: a prospective trial comparing anatomical reduction and valgus osteotomy. Injury 1990;21:84-8.

7. Yetkinler DN, Ladd AL, Poser RD, Constantz BR, Carter D. Biomechanical evaluation of fixation of intra-articular fractures of the distal part of the radius in cadavera: Kirschner wires compared with calcium-phosphate bone cement. J Bone Joint Surg [Am] 1999;81:391-9.

8. Oztürkmen $\mathrm{Y}$, Caniklioğlu $\mathrm{M}$, Karamehmetoğlu $\mathrm{M}$, Sükür E. Calcium phosphate cement augmentation in the treatment of depressed tibial plateau fractures with open reduction and internal fixation. Acta Orthop Traumatol Turc 2010;44:262-9.

9. Darby I. Periodontal materials. Aust Dent J 2011;56 Suppl 1:107-18.

10. Cift H, Deniz S, Ekşioğlu F. Determination of the effect on the proximal femoral load distribution of diaphyseal cement support in femoral intertrochanteric fractures with calcar defect by finite element analysis. [Article in Turkish] Eklem Hastalik Cerrahisi 2013;24:163-8. doi: 10.5606/ehc.2013.35.

11. Verron E, Khairoun I, Guicheux J, Bouler JM. Calcium phosphate biomaterials as bone drug delivery systems: a review. Drug Discov Today 2010;15:547-52.

12. Cohen SC, Gabelnick HL, Johnson RK, Goldin A. Effects of antineoplastic agents on wound healing in mice. Surgery 1975;78:238-44.

13. Greco F, de Palma L, Specchia N, Jacobelli S, Gaggini C. Polymethylmethacrylate-antiblastic drug compounds: an in vitro study assessing the cytotoxic effect in cancer 
cell lines--a new method for local chemotherapy of bone metastasis. Orthopedics 1992;15:189-94.

14. Hernigou P, Thiéry JP, Benoit J, Voisin MC, Leroux P, Hagege $\mathrm{G}$, et al. Methotrexate diffusion from acrylic cement. Local chemotherapy for bone tumours. J Bone Joint Surg [Br] 1989;71:804-11.

15. Rosa MA, Maccauro G, Sgambato A, Ardito R, Falcone G, De Santis V, et al. Acrylic cement added with antiblastics in the treatment of bone metastases. Ultrastructural and in vitro analysis. J Bone Joint Surg [Br] 2003;85:712-6.

16. Maccauro G, Cittadini A, Casarci M, Muratori F, De Angelis D, Piconi C, et al. Methotrexate-added acrylic cement: biological and physical properties. J Mater Sci Mater Med 2007;18:839-44.

17. Draenert FG, Draenert K. Methotrexate-loaded polymethylmethacrylate bone cement for local bone metastasis therapy: pilot animal study in the rabbit patellar groove. Chemotherapy 2008;54:412-6.

18. Bohner M, Gbureck U, Barralet JE. Technological issues for the development of more efficient calcium phosphate bone cements: a critical assessment. Biomaterials
2005;26:6423-9.

19. Bohner M. Silicon-substituted calcium phosphates - a critical view. Biomaterials. 2009;30:6403-6.

20. Li D, Yang Z, Li X, Li Z, Li J, Yang J. A histological evaluation on osteogenesis and resorption of methotrexateloaded calcium phosphate cement in vivo. Biomed Mater 2010;5:25007.

21. Bernards CM CJ, Mirza SK. Lethality of embolized norian bone cement varies with the time between mixing and embolization. Proceedings of the 50th Annual Meeting of the Orthopaedic Research Society (ORS); San Fransisco, USA. p. 254.

22. Postlethwaite AE, Seyer JM, Kang AH. Chemotactic attraction of human fibroblasts to type I, II, and III collagens and collagen-derived peptides. Proc Natl Acad Sci U S A 1978;75:871-5.

23. Ruszczak Z, Friess W. Collagen as a carrier for on-site delivery of antibacterial drugs. Adv Drug Deliv Rev 2003;55:1679-98.

24. Diegelmann RF, Evans MC. Wound healing: an overview of acute, fibrotic and delayed healing. Front Biosci 2004;9:283-9. 